\title{
PERSEPSI PENGUNJUNG TERHADAP OBJEK WISATA PANTAI GUMUMAE DI KECAMATAN BULA KABUPATEN SERAM BAGIAN TIMUR
}

\author{
VISITORS 'PERCEPTIONS OF THE GUMUMAE BEACH TOURIST ATTRACTION IN \\ BULA DISTRICT, EAST SERAM REGENCY
}

\author{
Marhamah S. N. Keliobas ${ }^{1)}$, Yosevita Th. Latupapua ${ }^{2)}$, C. K. Pattinasarany ${ }^{3)}$ \\ Jurusan Kehutanan, Fakulttas Pertanian, Universitas Pattimura \\ Penulis korespondensi email: marhamah.keliobas@gmail.com \\ \begin{tabular}{|l|l}
\hline Diterima : 13 Januari 2019 & Disetujui : 12 Februari 2019
\end{tabular}
}

\begin{abstract}
Abstrak
Persepsi pengunjung terhadap objek wisata Pantai Gumumae Kecamatan Bula Kabupaten Seram Bagian Timur adalah penelitian yang dilakukan dengan tujuan untuk mengetahui persepsi pengunjung terhadap objek wisata Pantai Gumumae yang ada pada Kecamatan Bula Kabupaten Seram Bagian Timur. Pemilihan lokasi penelitian dilakukan secara purposive, penelitian dilakukan pada bulan November-Desember 2018, dalam penelitian ini metode pengumpulan data yang digunakan berupa observasi langsung dilapangan, pembagian kuisioner/wawancara, dokumentasi, dan study pustaka. Analisa data penelitian menggunakan metode analisis deskriptif kualitatif untuk menjawab tujuan penelitian berdasarkan informasiinformasi yang didapatkan dari observasi dilapangan. Dari hasil penelitian dapat diketahui bahwa persepsi pengunjung terkait daya tarik dari objek wisata Pantai Gumumae memberikan penilaian menarik dengan persentase $80 \%$. Persepsi pengunjung terhadap fasilitas/amenitas dengan persentase baik 46,67\%, pelayanan makan mininum cukup baik dengan persentase $56,67 \%$, keamanan/keselamatan pantai kurang terjamin 48,33 , kebersihan pantai kurang baik $51,67 \%$, penambahan fasilitas perlu dilakukan $100 \%$, kepuasan dalam melakukan kunjungan $50 \%$, dan persepsi pengunjung terhadap aksesibilitas pada objek wisata Pantai Gumumae dinilai baik $86,67 \%$ serta moda angkutan umum pada objek lancar $48,33 \%$.
\end{abstract}

Kata kunci: Persepsi, engunjung, pantai gumumae

\begin{abstract}
Visitors 'perceptions of the Gumumae Beach tourist attraction in Bula District, East Seram Regency were research aimed to know visitors' perceptions of Gumumae Beach attractions in Bula District, East Seram District. The selection of research locations was conducted purposively in November-December 2018, in this study the data collection method used was in the form of direct observation in the field, distribution of questionnaires / interviews, documentation, and literature study. Analysis of research data using qualitative descriptive analysis methods to answer research objectives based on information obtained from field observations. From the results of the study, it can be seen that visitors' perceptions of attraction from Gumumae Beach attractions give an assessment that the beach scenery is an interesting with a percentage of $80 \%$. Visitors' perception of the facility/amenity the attractions provide an assessment officer friendliness associated with a good percentage of $46.67 \%$, mininum meal service is quite good $56.67 \%$, security / safety is not guaranteed 48.33 coast, beach cleanliness less good $51.67 \%$, additional facilities need to be done $100 \%$, satisfaction in making visits is $50 \%$ satisfied, and visitors' perceptions of accessibility on Gumumae Beach attractions are valued at $86.67 \%$ and smooth object public transportation modes $48.33 \%$.
\end{abstract}

Keywords: perception, visitors', Gumumae Beach 


\section{PENDAHULUAN}

Perkembangan pada dunia pariwisata dewasa ini mempunyai kontribusi yang cukup besar dalam pertumbuhan ekonomi di suatu negara pada era globalisasi kini, termasuk Indonesia. Keterlibatan pariwisata dalam pertumbuhan ekonomi tersebut dapat diukur dari penerimaan devisa, terciptanya lapangan pekerjaan, dan pengembangan usaha serta infrastruktur. Adanya potensi wisata pada suatu daerah dapat menjadi peluang yang besar bagi pengembangan pariwisata serta perekonomian pada daerah itu sendiri, sehingga perlu adanya perhatian khusus dalam peningkatan mutu pelayanan, pelestarian lingkungan wisata serta penyediaan sarana dan prasarana demi kemajuan pariwisata itu sendiri. Selain untuk berekreasi, dewasa ini kegiatan berwisata lebih mengarah pada jenis wisata yang natural atau kembali ke alam (back to nature), hal ini dikarenakan suasana lingkungan wisata yang berbeda dengan rutinitas wisatawan pada umumnya serta kepedulian masyarakat terhadap konservasi dan pelestarian alam yang lebih meningkat (Koranti, et al 2017).

Seiring dengan pertumbuhan pembangunan saat ini, maka semakin tinggi pula keinginan wisatawan terhadap tempat wisata dengan beragam fasilitas dan kegiatan serta aktifitas menarik lainnya. Persepsi wisatawanmenjadi patokan dalam memperhitungkan penilaian atau tanggapan serta keinginan juga kebutuhan akan pelayanan fasilitas wisata yang disediakan penyedia layanan wisata dan yang diterima oleh wisatawan. (Koranti, et al 2017)

Persepsi merupakan bagaimana individu mengerti dan menilai lingkungan sekitarnya (Sarwono, 1992 dalam Pauwah, 2013), setiap individu dapat menafsirkan sesuatu objek secara berbeda tergantung dari sudut pandang pribadi masing-masing individu. Hal ini dapat berimplikasi pada bervariasinya persepsi seseorang terhadap suatu objek yang sama (Kurniawan, 2013).Sehingga persepsi dari satu individu dapat digunakan oleh penyedia layanan wisata untuk melihat keinginan, tanggapan dan penilaian pengguna terhadap suatu objek yang akan direncanakan, dan dengan melihat persepsi pengunjung dapat memberikan masukan dan menjadi bentuk partisipasi dalam proses perencanaan. Persepsi pengunjung terhadap keberadaan objek sebenarnya mencerminkan pendapat, keinginan, harapan, dan tanggapan pengujung terhadap objek wisata tersebut. (Latupapua, 2011)

Maluku merupakan provinsi dengan julukan seribu pulau yang terkenal dengan wisata baharinya yang indah dan mengagumkan. Pada umumnya setiap pulau-pulau yang ada memiliki keadaan geografis yang berbeda, dengan keunikan serta kealamian pantai yang berbeda dengan pantai lainnya, sehingga berpeluang untuk dijadikan sebagai destinasi wisata yang 
dapat sangat menguntungkan bagi daerah tersebut.

Objek wisata Pantai Gumumae merupakan salah satu objek wisata pantai yang ada di Maluku khususnya di kota Bula, Kecamatan Bula, Kabupaten Seram Bagian Timur (SBT). Objek wisata Pantai Gumumae ini dikelola oleh Dinas Pariwisata Kabupaten Seram Bagian Timur sejak tahun 2005. Terletak pada ibukota kabupaten dan dekat dengan pusat Kota Bula, peluang ini menjadikan objek wisata Pantai Gumumae menjadi destinasi andalan masyarakat kota Bula dan sekitarnya. Selain berdasarkan letaknya yang strategis dan mudah dijangkau, karakteristik daya tarik objek wisata Pantai Gumumae juga dicirikan dengan tipe pantai berpasir coklat yang landai dan didominasi oleh vegetasi pesisir berupa kasuari pantai dan mangrove. Pantai ini juga merupakan lokasi yang cocok untuk menikmati fenomena sunset and sunrice dengan desiran ombak yang menderu. Objek wisata Pantai Gumumae memiliki beberapa kegiatan rekreasi yang dapat dilakukan pengunjung di antaranya adalah berfoto, berkemah, menikmati keindahan alam, berenang, bersantai, makan-makan, dan olah raga pantai.

Keindahan dan kealamian pantai Gumumae, perlu juga didukung dengan adanya kesiapan amenitas dan aksesibilitas yang dapat mempengaruhi lama kunjungan dan peningkatan jumlah kunjungan. Untuk itu tujuan dari penelitian ini adalah menganalisis persepsi pengunjung terhadap objek daya tarik pantai Gumumae Kecamatan Bula agar dapat dikembangkan sebagai objek potensial dalam menunjang kepuasan pengunjung.

\section{METODE PENELITIAN}

Penelitian ini telah dilaksanakan pada objek wisata Pantai Gumumae, Kecamatan Bula, Kabupaten Seram Bagian Timur, Provinsi Maluku. Pemilihan lokasi penelitian dilakukan dengan sengaja (pusposive) dengan berdasarkan pada pertimbangan bahwa objek wisata Pantai Gumumae merupakan objek wisata andalan di Kabupaten Seram Bagian Timur (SBT). Pengambilan data di lapangan dilaksanakan pada bulan November - Desember 2018.

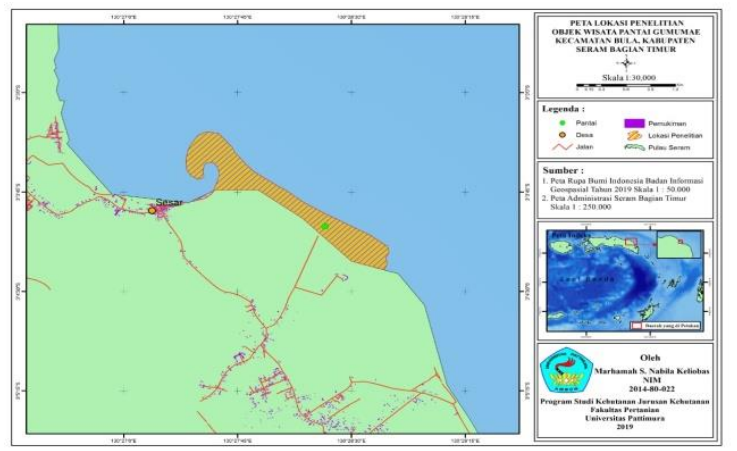

Gambar 1 Peta Lokasi Penelitian

Alat yang digunakan dalam penelitian ini berupa: Kuisioner, Kamera, Alat tulis menulis, Peta lokasi

Objek utama dalam penelitian ini adalah pengunjung objek wisata Pantai Gumumae di Kecamatan Bula Kabupaten Seram Bagian Timur (SBT).

Jenis dan sumber data yang digunakan dalam penelitian ini adalah : 
1. Data Primer, diperoleh secara langsung di lapangan melalui proses wawancara, kuisioner, observasi dan dokumentasi.

2. Data Sekunder meliputi hasil - hasil penelitian, jurnal, serta laporan/data dari instansi terkait yang relevan dengan tujuan penelitian.

Metode pengumumpulan data yang digunakan dalam penelitian ini adalah :

1. Observasi : pengamatan secara langsung dilapangan terhadap; 1.) Aktifitas pengelola objek wisata dan wisatawan pada objek wisata, 2.) Kondisi fisik objek wisata yang berkaitan dengan atraksi, aksesibilitas, dan amenitas yang ada pada objek wisata.

2. Kuisioner/wawancara

\begin{tabular}{lrrr} 
Kuisioner merupakan & teknik \\
pengumpulan data yang & efisien. \\
Kuisioner & \multicolumn{4}{r}{ merupakan } \\
pernyataan/pertanyaan & yang & diberikan
\end{tabular} kepada responden secara langsung untuk dijawab. Pemilihan sampel menggunakan metode accidental sampling, yaitu tiap pengunjung yang secara kebetulan bertemu dengan peneliti akan dijadikan sebagai sampel. Untuk mengetahui jumlah responden digunakan rumus sebagai berikut (Sevilla, 2006 dalam Latupapua, 2007) :

$$
\mathrm{n}=\frac{N}{1+N e^{2}}
$$

Di mana :

$\mathrm{n}=$ jumlah responden
$\mathrm{N}=$ ukuran populasi

$\mathrm{e}=$ nilai kritis (batas ketelitian 0,1 sampai $0,2)$

Mengacu pada data jumlah kunjungan wisatawan Pantai Gumumae pada tahun 2017 (Dinas Pariwisata Kabupaten Seram Bagian Timur, 2018) yaitu berjumlah 7.075 orang atau dengan asumsi rata-rata 147 orang setiap minggu. Penjumlahan untuk mendapatkan jumlah responden dengan menggunakan ukuran populasi 147 orang tiap minggu dan nilai kritis 0,1 . Sehingga jumlah responden yang didapat berdasarkan rumus diatas yaitu berjumlah 59,5 dan dibulatkan menjadi 60 orang agar memperoleh hasil yang lebih akurat.

3. Dokumentasi

Merupakan teknik pengumpulan data dengan mendokumentasikan sumber di lapangan yang bersangkutan dengan penelitian.

4. Studi Pustaka sebagai referensi penunjang penelitian, referensi ini berupa buku pustaka, hasil penelitian serupa, maupun jurnal, untuk mengumpulkan data yang relevan dengan penilitian ini.

Dalam penelitian ini metode analisis data yang digunakan berupa metode deskriptif kualitatif yang bertujuan untuk menjawab tujuan penelitian berdasarkan informasi-informasi yang didapatkan dari observasi di lapangan (Koranti, at al 2017). 
Pengambilan data responden di lapangan dilakukan melalui pengisian kuisioner oleh responden, dan kemudian data-data yang telah terkumpul tersebut diinterpretasikan dalam bentuk bahasa tulisan dengan mengembangkan berbagai pemikiran dan gagasan serta pedoman pada teori dan literatur yang tersedia untuk menggambarkan kenyataan di lapangan. Dengan demikian analisis deskriptif kulititatif diharapkan dapat memberikan gambaran tentangkarakteristik persepsi pengunjung terhadap objek wisata Pantai Gumumae di Kecamatan Bula Kabupaten Seram Bagian Timur (SBT).

\section{HASIL DAN PEMBAHASAN}

\section{Pantai Gumumae}

Berdasarkan data hasil penilitian dan observasi langsung di lapangan, dapat dikemukakan bahwa objek wisata Pantai Gumumae memiliki pesona daya tarik alam yang masih alami. Dari segi ekologis pantai, semua vegetasi yang tumbuh rapih pada objek wisata Pantai Gumumae tumbuh secara alami dan bukan buatan, sehingga hal tersebut menambah ciri khas dan menjad daya tarik Pantai Gumumae. Pantai Gumumae merupakan pantai yang memiliki panorama indah dengan berbagai jenis flora dan fauna sekitar pantai diantaranya flora berupa kasuari pantai (Casuarina Equisetifolia), mangrove (Rhizophora spp \& Sonneratia spp), kayu marsegu (Anthocephalus Cadamba), ketapang
(Terminalia catappa), kayu waru (Hibiscus Tiliaceus), mengkudu (Morinda Citrifolia), dan kelapa (Cocos Nucifera), serta fauna berupa elang pantai (Haliastur Indus), burung gereja (Passer Montanus), walet (Apodidae spp), perkici (Trichoglosus spp), ular (Phyton spp), belut laut (Muraena Helena), ikan (Paraphyletic), kepiting (Scylla spp), kerang (Bivalvia spp), siput (Gastropoda spp), dan kupu-kupu (Lepidoptera spp). serta ciri lain dari Pantai Gumumae yaitu memiliki tipe pantai yang landai dan panjang dengan pasir yang berwarna coklat dan luas arel Pantai Gumumae \pm 50 hektar dengan panjang pantai 3,2 km dan lebar pantai $129 \mathrm{~m}$. Pantai Gumumae juga memiliki pesona yang indah terutama pada sore hari dengan air laut yang tenang yang memantulkan cahaya matahari terbenam berwarna kuning kemerahan. Objek wisata ini biasanya digunakan sebagai tempat bermain, bersantai, refresing keluarga, dan juga dipergunakan dalam aktivitas olahraga antara lain berenang, voli pantai, bola kaki, dan lain-lain.

Keadaan lingkungan sekitar objek wisata Pantai Gumumae masih terlihat asri dan terkesan dijaga pemeliharaan lingkungannya, hal ini terlihat pada saat observasi langsung ke lokasi Pantai Gumumae. Tidak terlihat adanya kegiatan penebangan atau pengambilan pasir pantai oleh masyarakat dalam upaya untuk memenuhi kebutuhan kayu bakar atau 
bahan bangunan. Pantai terlihat rapih dengan pohon-pohon yang ada menambah suasana sejuk dan indah serta nyaman. Gambaran objek wisata Pantai Gumumae dapat dilihat pada gambar 2 berikut.

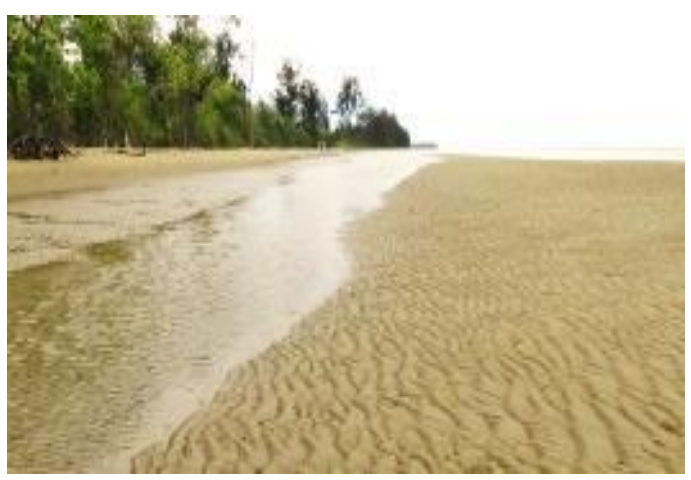

Gambar 2 Panorama Pasir Pantai

Gumumae

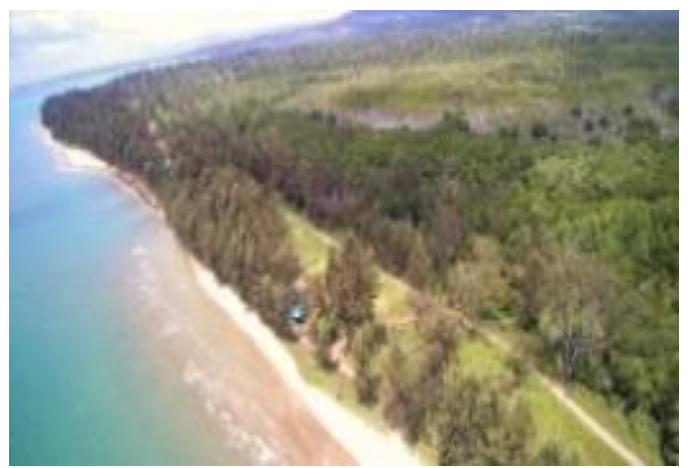

Gambar 3 Lansekap Pantai Gumumae

Pantai Gumumae terletak di desa Sesar Kecamatan Bula Kabupaten Seram Bagian Timur (SBT) dan merupakan lokasi wisata yang cukup terkenal di Kabupaten Seram Bagian Timur. Pantai yang terletak sekitar 6 kilometer dari pusat kota Bula tersebut sering menjadi pilihan utama masyarakat kota Bula dan sekitarnya. Akses menuju ke objek dapat ditempuh dalam waktu \pm 10 menit dari pusat kota Bula hingga mencapai gerbang pantai, selanjutnya pengunjung akan menyusuri jalan beraspal sejauh 1,4 kilometer dari gerbang pantai kearah timur laut.

Untuk memasuki lokasi Pantai Gumumae pengunjung terlebih dahulu membayar harga tanda masuk (HTM) Rp. 2.000 perorang, Rp 10.000 untuk kendaraan roda empat dan Rp 5.000 untuk kendaraan roda dua serta sudah termasuk didalamnya biaya parkir. Didalam lokasi Pantai Gumumae telah disediakan fasilitas wisata berupa gazebo-gazebo atau tempat santai untuk pengunjung, tempat parkir, kios makan, jalan setapak, papan informasi, tempat penyewaan ban pelampung, dan juga WC umum.

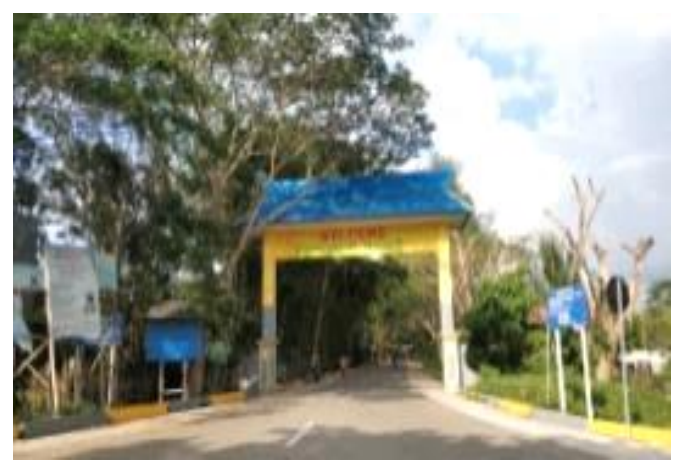

Gambar 4 Gerbang Masuk Utama

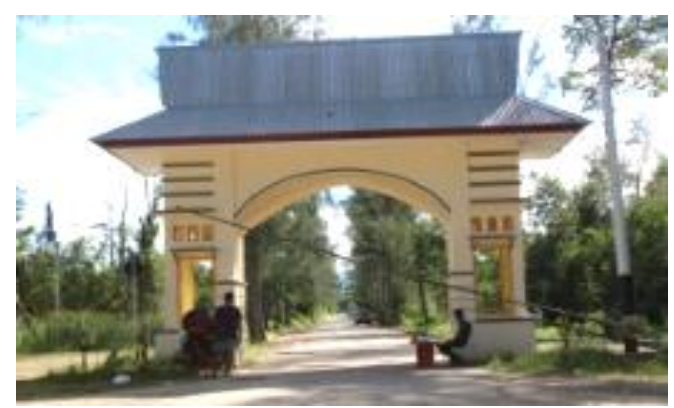

Gambar 5 Loket Masuk 


\section{Profil Wisatawan}

Berdasarkan hasil observasi dan kuisioner, dapat disebutkan bahwa profil wisatawan yang berkunjung ke objek wisata Pantai Gumumae bisa dilihat dari struktur wisatawan dan karakteristik dari kunjungan wisata. Untuk mengetahui gambaran struktur wisatawan dan karakteristik bisa di dekati dengan indikator-indikator seperti jenis kelamin, asal tempat, umur, pendidikan, jenis pekerjaan, motivasi dan jenis aktivitas. Berikut ini diuraikan mengenai indikator-indikator tersebut yang diperoleh dari hasil pembagian kuisioner kepada 60 responden di objek wisata Pantai Gumumae. Dapat dilihat pada tabel 1 berikut.

Tabel 1 Profil Pengunjung Objek Wisata Pantai Gumumae

\begin{tabular}{|c|c|c|c|}
\hline No. & Kriteria & $\begin{array}{c}\text { Frekuensi } \\
\text { (Jumlah } \\
\text { Responden) }\end{array}$ & Persentase \\
\hline \multirow[t]{5}{*}{1} & Umur & & \\
\hline & $<16$ & - & $0 \%$ \\
\hline & $16-26$ & 39 & $65 \%$ \\
\hline & $27-38$ & 17 & $28,33 \%$ \\
\hline & $39>$ & 4 & $6,67 \%$ \\
\hline \multirow[t]{3}{*}{2} & Jenis kelamin & & \\
\hline & Laki-laki & 33 & $55 \%$ \\
\hline & Perempuan & 27 & $45 \%$ \\
\hline \multirow[t]{3}{*}{3} & Asal/tempat tinggal & & \\
\hline & Lokal & 57 & $95 \%$ \\
\hline & Nusantara & 3 & $5 \%$ \\
\hline \multirow[t]{6}{*}{4} & Pendidikan terakhir & & \\
\hline & SD & 1 & $1,67 \%$ \\
\hline & SMP & 2 & $3,33 \%$ \\
\hline & SMA Sederajat & 33 & $55 \%$ \\
\hline & S1 & 20 & $33,33 \%$ \\
\hline & D3 & 4 & $6,67 \%$ \\
\hline \multirow[t]{5}{*}{5} & Pekerjaan & & \\
\hline & Mahasiswa/Pelajar & 25 & $41,67 \%$ \\
\hline & PNS & 14 & $23,33 \%$ \\
\hline & TNI/POLRI & 8 & $13,33 \%$ \\
\hline & Wirausaha & 13 & $21,67 \%$ \\
\hline
\end{tabular}

Berdasarkan hasil penelitian yang disajikan pada Tabel.1 diatas dapat diketahui bahwa jumlah pengunjung pada objek wisata Pantai Gumumae di dominasi oleh kelompok usia 16-26 tahun (65\%) diikuti dengan usia 27-38 (28,33\%) dan usia >39 (6,67\%). Hal ini dikarenakan pada usia ini orang lebih enerjik dan bersemangat serta senang melakukan perjalanan untuk mencari pengalaman baru ke tempat-tempat yang menarik. Hal ini juga serupa dengan penelitian yang dilakukan oleh Koranti, et al (2017) yang menyatakan bahwa pada umumnya kelompok dengan usia 16-26 tahun adalah merupakan usia dimana orang lebih berenergi, sehingga diperkirakan pada usia ini orang lebih suka melakukan perjalanan untuk mencari pengalaman baru dan mendatangi tempat yang lebih menarik. Karena objek wisata Pantai Gumumae ini lebih didominasi oleh kelompok usia muda maka perlu diperhatikan fasilitas-fasilitas penunjang yang digemari dan dapat memacu adrenalin seperti penempatan flying fox, banana both, ski air, spot foto yang menarik, rumah pohon, jembatan jaring gantung, dan atraksi-atraksi buatan lainnya yang dapat menarik minat pengunjung kalangan ini.

Jumlah pengunjung objek wisata Pantai Gumumae dilihat berdasarkan jenis kelamin menujukan laki-laki dan perempuan relatif lebih merata, laki-laki (55\%) danperempuan (45\%). Meskipun di dominasioleh laki-laki namun tidak begitu signifikan perbedaanya, sehingga tidak dapat dikatakan bahwa objek wisata Pantai 
Gumumae merupakan objek wisata yang lebih banyak diminati oleh wisatawan dengan jenis kelamin laki-laki. Seperti dinyatakan Keliwar dan Nurcahyo (2015) bahwa antara laki-laki dan perempuan sama-sama memiliki motivasi yang sama untuk melakukan kegiatan wisata. Hal ini juga menunjukkan bahwa objek wisata Pantai Gumumae merupakan obyek wisata yang dapat dinikmati oleh laki-laki maupun perempuan, sehingga dalam pengembangannya perlu diperhatikan juga hal-hal yang dapat dilakukan oleh jenis kelamin laki-laki maupun perempuan.

Pengunjung objek wisata Pantai Gumumae di dominasi oleh pengunjung lokal (95\%). Hal ini dikarenakan aksesibilitas untuk mencapai objek wisata yang mudah untuk ditempuh. Sejalan dengan Keliwar dan Nurcahyo (2015), yang menyimpulkan bahwa jarak tempuh (akses) menjadi salah satu faktor yang turut menentukan kunjungan pengunjung ke suatu objek wisata. Dilihat dari hasil keragaman pengunjung objek wisata Pantai Gumumae berdasarkan asal/tempat tinggal yang didominasi oleh pengunjung lokal maka perlu adanya promosi lebih dari pihak pengelola serta penambahan fasilitas dan atraksi wisata yang dapat menarik bukan hanya pengunjung lokal namun juga pengunjung nusantara ataupun mancanegara seperti penambahan atraksi budaya atau penjualan makanan khas daerah.
Pengunjung pada objek wisata Pantai Gumumae berdasarkan tingkat pendidikan terakhir relatif didominasi oleh SMA dan sederajat (55\%) dan disusul dengan S1 (33,33\%). Hal ini perlu diperhatikan sebab tingkat pendidikan dapat berpengaruh terhadap jenis aktifitas wisata yang akan dilakukan serta permintaan terhadap kualitas pelayanan dan fasilitas yang ditawarkan sehingga perlu perhatian lebih lanjut. Hal ini sejalan dengan penelitian yang dilakukan oleh Dwiputra (2013) yang menegaskan bahwa tingkat pendidikan dapatmenjadi salah satu faktor pertimbangan terhadap permintaan, dimana tingkat pendidikanakan mempengaruhi pada aktivitas kegiatan, pelayanan, dan kualitas fasilitas di objek wisata. Penambahan fasilitas penunjang wisata yang dapat berguna untuk menambah informasi sebagai sarana edukasi bagi pengunjung objek wisata juga perlu dipertimbangkan, seperti pengenalan flora dan penempatan fauna pada objek sebagai media pembelajaran.

Pengunjung objek wisata Pantai Gumumae berdasarkan jenis pekerjaannya didominasi oleh mahasiswa/pelajar $(41,67 \%)$. Fakta ini berkorelasi dengan hasil sebelumnya yang menyatakan bahwa objek wisata Pantai Gumumae didominasi oleh pengunjung dengan usia 16-26 tahun yang dimana pada usia ini orang akan lebih senang melakukan perjalanan untuk mencari pengalaman baru dan lebih 
berenerjik, selain itu mereka juga cenderung lebih suka bersama temantemannya, tidak terkecuali dalam mengunjungi objek wisata. serupa dengan Dwiputra (2013) yang mengatakan bahwa mayoritas wisatawan yang berkunjung keobjek wisata adalah yang suka mencari pengalaman baru yaitu pelajar dan mahasiswa, kelompok ini juga banyak berdatangan bersama teman pelajar/mahasiswa lainya. Dengan demikian disebutkan kembali bahwa pihak pengelola wisata perlu memperhatikan kegiatankegiatan yang dapat dinikmati dan menarik bagi anak muda lebih khususnya pelajar/mahasiswa.

\section{Kondisi Kunjungan Ke Objek Wisata Pantai Gumumae.}

Tabel 2 Kondisi Kunjungan Ke Objek Wisata Pantai Gumumae

\begin{tabular}{|c|c|c|c|}
\hline $\begin{array}{l}\mathrm{N} \\
\mathrm{O}\end{array}$ & Kajian & $\begin{array}{l}\text { Frekuensi } \\
\text { (Jumlah } \\
\text { Responde } \\
\text { n) }\end{array}$ & $\begin{array}{c}\text { Persentas } \\
\text { e }\end{array}$ \\
\hline \multirow[t]{3}{*}{1} & Tujuan berkunjung & & \\
\hline & - Berlibur & 35 & $96,67 \%$ \\
\hline & - $\quad$ Berenang & 2 & $3,33 \%$ \\
\hline \multirow[t]{6}{*}{2} & Berapa kali kunjungan & & \\
\hline & - Pertama kali & 9 & $15 \%$ \\
\hline & - $2-3$ & 7 & $11,67 \%$ \\
\hline & - $4-10$ & 4 & $6,67 \%$ \\
\hline & - $\quad>10$ & 31 & $51,67 \%$ \\
\hline & - $\quad$ Tak terhitung & 9 & $15 \%$ \\
\hline \multirow[t]{5}{*}{3} & Kapan melakukan & & \\
\hline & kunjungan & 23 & $38,33 \%$ \\
\hline & • Hari libur & 20 & $33,33 \%$ \\
\hline & - $\quad$ Waktu luang & 17 & $28,33 \%$ \\
\hline & • Hari minggu & & \\
\hline \multirow[t]{5}{*}{4} & Mengetahui objek dari & & \\
\hline & - Masyarakat & 22 & $36,67 \%$ \\
\hline & - Teman & 21 & $35 \%$ \\
\hline & - $\quad$ Sosial media & 8 & $13,33 \%$ \\
\hline & - Kerabat & 9 & $15 \%$ \\
\hline \multirow[t]{4}{*}{5} & Lama kunjungan & & \\
\hline & - 1-3 jam & 36 & $60 \%$ \\
\hline & - $3-5$ jam & 19 & $31,67 \%$ \\
\hline & - Sepuasnya & 5 & $8,33 \%$ \\
\hline \multirow[t]{3}{*}{6} & Aktifitas saat berkunjung & & \\
\hline & - Bersantai & 17 & $28,33 \%$ \\
\hline & - Berfoto & 12 & $20 \%$ \\
\hline
\end{tabular}

\begin{tabular}{|c|c|c|c|}
\hline & $\begin{array}{ll}\text { - } & \text { Berenang } \\
\text { - } & \text { Bermain pasir } \\
\text { - } & \text { Makan-makan }\end{array}$ & $\begin{array}{c}10 \\
15 \\
6\end{array}$ & $\begin{array}{c}16,67 \% \\
25 \% \\
10 \%\end{array}$ \\
\hline 7 & $\begin{array}{cl}\text { Bentuk kunjungan } \\
\text { • } & \text { Rombongan } \\
\text { - } & \text { Keluarga } \\
\text { - } & \text { Berdua } \\
\text { - } & \text { Sendiri } \\
\end{array}$ & $\begin{array}{c}30 \\
24 \\
5 \\
1\end{array}$ & $\begin{array}{c}50 \% \\
40 \% \\
8,33 \% \\
1,67 \%\end{array}$ \\
\hline 8 & 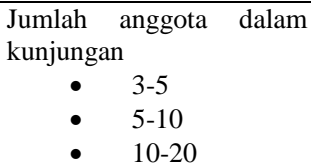 & $\begin{array}{c}3 \\
42 \\
15\end{array}$ & $\begin{array}{l}5 \% \\
70 \% \\
25 \%\end{array}$ \\
\hline
\end{tabular}

Berdasakan data hasil penelitian yang disajikan pada tabel .2 di atas dapat diketahui bahwa tujuan sebagian besar wisatawan berkunjung ke objek wisata Pantai Gumumae adalah untuk berlibur $(58,33 \%)$. Hal ini dilakukan pengunjung untuk sekedar refresing dan bersantai untuk melepaskan penat setelah bekerja pada harihari biasa. Sesuai dengan penelitian yang dilakukan Saragih (2015), yang menyatakan bahwa pengunjung melakukan kunjungan dengan tujuan untuk melepaskan kelelahan diantaranya seperti bersantai, refresing demi untuk menikmati liburan dan melepaskan penat serta memanfaatkan waktu luangnya. Kebanyakan pengunjung juga sudah lebih dari 10 kali berkunjung pada objek wisata Pantai Gumumae (51,67\%). Hal ini menunjukkan bahwa objek wisata Pantai Gumumae memiliki daya tarik yang baik dan pelayanan yang diberikan oleh pengelola sudah memenuhi standar kriteria bagi pengunjung serta akses dan moda transportasi menuju objek yang mudah menyebabkan kunjungan dapat dilakukan secara berulang. Seperti yang dikemukakan Keliwar dan Nurcahyo 
(2015), bahwa pengunjung yang melakukan kunjungan secara berulang-ulang menunjukan bahwa objek wisata tersebut memang memiliki daya tarik yang dapat menarik pengunjung untuk datang berulang kali.

Hasil penelitian menunjukkan sebagian besar pengunjung melakukan kunjungan pada hari libur $(38,33 \%)$. Hal ini menunjukan bahwa Pantai Gumumae sebagai objek wisata andalan pilihan pengunjung yang cocok dijadikan tempat untuk menghabiskan waktu libur. Pengunjung objek wisata Pantai Gumumae kebanyakan mengetahui objek wisata dari informasi masyarakat sekitar $(36,67 \%)$ dan dari teman (35\%). Informasi dari masyarakat sekitar dan teman diperoleh dari mulut ke mulut ketika mereka saling berkomunikasi. Koranti, et al (2017), juga menyatakan bahwa keberadaan sebuah objek wisata dapat diperoleh wisatawan dari berbagai sumber informasi.

Lama kunjungan pada objek wisata Pantai Gumumae didominasi 1-3 jam (60\%). Lamanya waktu kunjungan berkaitan dengan terpenuhinya tujuan berwisata, tingkat kenyamanan pengunjung saat berada pada objek wisata dan banyaknya aktifitas wisata serta fasilitas wisata yang ditawarkan objek. Hal ini serupa dengan penelitian yang dilakukan oleh Koranti, et al (2017) yang menyatakan bahwa lamanya waktu kunjungan berhubungan dengan tujuan dan motivasi wisatawan untuk berkunjung.

Hasil penelitian juga menunjukkan bahwa aktifitas wisata yang paling disenangi oleh pengunjung untuk dilakukan kebanyakan adalah bersantai $(28,33 \%)$ dan berfoto (20\%). Hal ini dikarenakan suasana Pantai Gumumae yang alami dan tenang membawa kenyamanan kepada pengunjung, selain itu juga aktifitas yang dilakukan pada saat melakukan kunjungan antara lain berenang, bermain pasir, makan-makan, menikmati pemandangan, dan olahraga. Pendapat yang sama juga dikemukakan dalam hasil penelitian Samehe (2015), bahwa aktifitas yang disenangi pengunjung untuk dilakukan antara lain berjalan-jalan, berenang, berjemur, bermain pasir, dan makan-makan.

Pengunjung objek wisata Pantai Gumumae juga lebih senang melakukan kunjungan dalam bentuk rombongan (50\%) dan bersama keluarga (40\%). Dan kebanyakan jumlah anggota dalam melakukan kunjungan wisata berjumlah 510 orang (70\%). Kondisi ini dapat diartikan bahwa Pantai Gumumae dianggap sebagai objek wisata yang cukup menarik sehingga wisatawan mempunyai keinginan untuk berkunjung menikmati panorama pantai bersama rekan atau keluarga sambil menghilangkan penat dari rutinitas. Hal ini juga didukung oleh Dwiputra (2013), dalam hasil penelitiannya yang mengungkapkan bahwa kebanyakan 
pengunjung objek wisata melakukan kunjungan bersama rekan/teman dan keluarga.

\section{Persepsi Pengunjung Terkait Daya Tarik Objek Wisata Pantai Gumumae}

Berdasarkan persepsi pengunjung dapat diketahui tentang kondisi daya tarik objek wisata Pantai Gumumae. Penilaian pengunjung ini terkait dengan apa saja yang menarik dari objek wisata Pantai Gumumae dapat dilihat pada Tabel 3. berikut ini.

Tabel. 3 Persepsi Pengunjung Terkait Daya Tarik Objek Wisata Pantai Gumumae

\begin{tabular}{|c|c|c|c|}
\hline No & Daya tarik objek & $\begin{array}{c}\text { Frekuensi (Jumlah } \\
\text { Rosponden) }\end{array}$ & Persentase \\
\hline \multirow[t]{4}{*}{1} & $\begin{array}{lll}\begin{array}{l}\text { Yang } \\
\text { objek }\end{array} & & \\
\end{array}$ & & \\
\hline & $\begin{array}{l}\text { - Pemandangan } \\
\text { pantai }\end{array}$ & 52 & $86,66 \%$ \\
\hline & $\begin{array}{l}\text { - Tulisan } \\
\text { gumumae beach }\end{array}$ & 6 & $10 \%$ \\
\hline & - Gazebo & 2 & $3,33 \%$ \\
\hline
\end{tabular}

Dapat dilihat berdasarkan hasil analisa yang disajikan pada tabel 3 diatas menunjukan bahwa yang paling menarik bagi pengunjung untuk melakukan kunjungan ke objek wisata Pantai Gumumae ini adalah karena pemandangan pantainya $(86,66 \%)$, hal ini dikarenakan suasana alam terbuka dengan vegetasi kasuari pantai yang berjajar sepanjang pantai menciptakan lingkungan yang sejuk dan tidak berpolusi serta kondisi pantainya yang tidak terlalu dalam dan tenang juga cenderung dangkal dan laut lepasnya yang membebaskan pengunjung untuk melihat tanpa ada penghalang serta pemandangan pantai saat sore hari menambah kenyamanan pengunjung, hal ini menjadi penggerak yang menarik pengunjung untuk dapat berkunjung dan menikmatinya. Serupa dengan penelitian yang dilakukan oleh Rare, et al (2017), menyatakan bahwa, daya tarik yang terdapat pada objek wisata yang sangat berpotensi dapat menarik pengunjung untuk datang berkunjung pada objek wisata. Latupapua (2007), juga menyatakan bahwa panorama alam yang masih alami karena lingkungan yang tercipta sekitar objek benar-benar terasa sejuk, tidak berpolusi, sehingga membawa perasaan nyaman dan damai jika bisa berada pada objek tersebut. Ismayanti (2010), juga menjelaskan bahwa daya tarik wisata terutama pemandangan pantai Dikemukakan dalam hasil penelitian Latupapua (2011), bahwa nilai potensi pemandangan pantai yang indah sangat mentukan minat wisatawan sehingga menambah kenyamanan wisatawan untuk datang berkunjung dan menikmatinya.

\section{Persepsi Pengunjung Terhadap Fasilitas /Amenitas Pada Objek Wisata Pantai Gumumae}

Berdasarkan data hasil wawancara, didapatkan gambaran wisata Pantai Gumumae kedepan. Persepsi pengunjung terhadap objek wisata Pantai Gumumae dapat di lihat pada Tabel 4.

Tabel 4 Persepsi Pengunjung Terhadap Fasilitas/Amenitas Pada Objek Wisata Pantai Gumumae

\begin{tabular}{lcc}
\hline No Tanggapan Pengunjung & $\begin{array}{c}\text { Frekuensi } \\
\text { (Jumlah } \\
\text { Responden) }\end{array}$ & \\
\hline
\end{tabular}




\begin{tabular}{|c|c|c|c|}
\hline 1 & \begin{tabular}{ll}
\multicolumn{2}{c}{ Keramahan petugas } \\
- & Baik \\
- & Cukup baik \\
- & Kurang baik \\
\end{tabular} & $\begin{array}{c}28 \\
23 \\
9\end{array}$ & $\begin{array}{c}46,67 \% \\
38,33 \% \\
15 \%\end{array}$ \\
\hline 2 & $\begin{array}{l}\text { Pelayanan makan } \\
\text { minum } \\
\text { - } \quad \text { Baik } \\
\text { - } \quad \text { Cukup baik } \\
\text { - } \quad \text { Kurang baik } \\
\end{array}$ & $\begin{array}{l}14 \\
34 \\
12\end{array}$ & $\begin{array}{c}23,33 \% \\
56,67 \% \\
20 \%\end{array}$ \\
\hline 3 & \begin{tabular}{ll}
\multicolumn{2}{l}{ Keamanan/Keselamatan } \\
- & Terjamin \\
- & Kurang terjamin \\
- & Tidak terjamin \\
\end{tabular} & $\begin{array}{c}22 \\
29 \\
9 \\
\end{array}$ & $\begin{array}{c}36,67 \% \\
48,33 \% \\
15 \% \\
\end{array}$ \\
\hline 4 & $\begin{array}{ll}\text { Kebersihan objek } \\
\text { - } & \text { Sangat baik } \\
\text { - } & \text { Kurang baik } \\
\text { - } & \text { Sangat kotor }\end{array}$ & $\begin{array}{c}9 \\
31 \\
20\end{array}$ & $\begin{array}{c}15 \% \\
51,67 \% \\
33,33 \%\end{array}$ \\
\hline 7 & \begin{tabular}{ll}
\multicolumn{2}{l}{ Perlu penambahan } \\
fasilitas \\
- $\quad$ Perlu \\
- $\quad$ Kurang perlu \\
- $\quad$ Tidak perlu \\
\end{tabular} & $\begin{array}{c}60 \\
- \\
-\end{array}$ & $\begin{array}{c}100 \% \\
- \\
-\end{array}$ \\
\hline 8 & $\begin{array}{l}\text { Kepuasan dalam } \\
\text { melakukan kunjungan } \\
\text { - } \quad \text { Sudah } \\
\text { - } \quad \text { Belum } \\
\text { - } \quad \text { Kurang puas }\end{array}$ & $\begin{array}{c}30 \\
28 \\
2\end{array}$ & $\begin{array}{c}50 \% \\
46,67 \% \\
3,33 \%\end{array}$ \\
\hline
\end{tabular}

Berdasarkan pada hasil analisis pada Tabel 4 dapat dijelaskan bahwa persepsi pengunjung terhadap keramahan petugas didominasi dengan jawaban baik (46,67\%). Hal ini menunjukan bahwa sebagian besar pengunjung merasa nyaman dan puas dengan pelayanan petugas selama menikmati objek wisata Pantai Gumumae, namun masih ada pengunjung yang merasa keramahan petugas kurang baik, sehingga perlu menjadi perhatian pihak pengelola agar keramahan petugas lebih ditingkatkan.

Pelayanan terkait Food and beverage mendapat penilaian baik sebesar (56,67\%). Hal ini ditunjang dengan tersedianya tempat makan yang strategis pada lokasi wisata Pantai Gumumae yang berada dekat dengan gerbang masuk serta kebersihan tempatnya yang terjaga, namun tidak sedikit pengunjung yang merasa tempat makan atau tempat jualan pada objek wisata masih kurang jumlahnya serta beragamnya pilihan menu pada lokasi objek wisata juga terbilang kurang bervariasi, hal ini tentunya mempengaruhi minat beli dari pengunjung.. Sejalan dengan penelitian yang dilakukan oleh Kurniawan (2013) yang mengemukakan bahwa penilaian pada pelayanan makan dan minum terletak pada aspek bagaimana tata letaknya, kebersihan, dan jumlah jenis yang disediakan bagi pengunjung.

Berdasarkan hasil perhitungan terkait dengan tingkat keamanan/keselamatan pantai, (48,33\%) menjawab kurang terjamin dan terjamin $(36,67 \%)$. Hal ini dikarenakan tidak adanya pengawas pantai yang di sediakan oleh pengelola objek, sehingga hal ini cukup menghawatirkan sebagian pengunjung, maka perlu adanya perhatian khusus terkait dengan keamanan serta keselamatan pantai. Pendapat serupa dikemukakan dalam hasil penelitian Kurniawan (2013), bahwa perlu adanya peningkatan dalam upaya memperketat keamanan objek wisata sehingga pengunjung lebih merasa aman dan nyaman. Namun kondisi pantai yang dangkal dan tidak terlalu dalam serta ombak pantai yang tidak terlalu besar membuat sebagian pengunjung masih tetap beraktifitas dalam berwisata secara aman dan tidak terlalu khawatir terhadap keselamatan diri dan anak-anak saat berada dalam pantai . 
Persepsi terkait Kebersihan pantai sebagian besar pengunjung memberikan jawaban kurang baik (51,67\%), sangat kotor $(33,33 \%)$. Hal ini dikarenakan hanya pada bagain-bagian tertentu dan saat-saat tertentu saja keadaan pantai menjadi bersih, sedangkan pada hari-hari biasa kebanyakan banyak sampah berserakan pada jalan-jalan setapak juga pada gazebo-gazebo dan sekitarnya. Dalam peluang datangnya kunjungan ke suatu destinasi wisata, juga dipengaruhi oleh kondisi kebersihan pantai (Latupapua, 2011)

Harapan pengunjung terkait hal tersebut perlu diperhatikan oleh pengelola objek karena berkaitan dengan kenyamanan pengunjung

Berdasarkan perlu tidaknya penambahan fasilitas pada objek wisata, seluruh responden menjawab perlu (100\%) penambahan fasilitas lebih diprioritasnya pada hal-hal terkait perlu adanya musholah dan sarana bermainan anak, perbaikan tracking mangrove, penambahan lampu jalan, gazebo, spot foto, rumah makan, taman olah raga, air bersih, tempat sampah, serta wahana bermain air.

\section{Persepsi Pengunjung Terhadap Aksesibilitas Pada Objek Wisata Pantai Gumumae}

Tabel.5 Persepsi Pengunjung Terhadap Aksesibilitas Pada Objek Wisata Pantai Gumumae

\begin{tabular}{|c|c|c|c|}
\hline No & Tanggapan Pengunjung & $\begin{array}{c}\text { Frekuensi } \\
\text { (Jumlah } \\
\text { Responden) }\end{array}$ & Persentase \\
\hline \multirow[t]{4}{*}{1} & Aksesibilitas & & \\
\hline & • Baik & 52 & $86,67 \%$ \\
\hline & - $\quad$ Kurang baik & 7 & $11,67 \%$ \\
\hline & - $\quad$ Tidak baik & 1 & $1,67 \%$ \\
\hline \multirow[t]{5}{*}{2} & Moda angkutan umum & & \\
\hline & - Lancar & 29 & $48,33 \%$ \\
\hline & - $\quad$ Cuckup & 24 & $40 \%$ \\
\hline & lancar & 7 & $11,67 \%$ \\
\hline & - Tidak lancar & & \\
\hline
\end{tabular}

Sumber: Data Primer, 2019

Berdasarkan data hasil analisis yang disajikan dalam tabel 5 menunjukkan bahwa persepsi terkait aksesibilitas baik (86,67\%). Hal ini disebabkan karena lokasi objek wisata Pantai Gumumae yang berada pada kota Bula dan akses jalan menuju objek wisata yang baik dan memadai yang ditunjang dengan jalan hotmix, yang ditunjang dengan moda transportasi yang beragam, sehingga untuk mencapai lokasi objek wisata pengunjung hanya membutuhkan waktu \pm 10 menit dari pusat kota Bula dengan menggunakan kendaraan roda dua maupun kendaraan roda empat. $n$ Botha (2015), dalam hasil penelitiannya mengemukakan bahwa penilaian pengunjung terkait akses menuju objek baik, menunjukan bahwa akses jalan tidak menimbulkan kesulitan bagi para pengguna jalan. Terkait moda angkutan menuju objek wisata Pantai Gumumae (48,33\%) menjawab lancar. Hal ini dikarenakan lancarnya angkutan umum yang melintasi objek wisata dari pukul 6.00 WIT sampai pukul 23.00 WIT, dengan harga yang cukup 
terjangkau yaitu berkisar antara Rp 2.000 Rp 5.000 .

\section{KESIMPULAN DAN SARAN}

\section{Kesimpulan}

Berdasarkan uraian pada hasil dan pembahasan maka kesimpulan yang diberikan adalah Persepsi pengunjung terkait dengan objek daya tarik pantai Gumumae, amenitas dan aksesibilitas adalah baik.

\section{Saran}

1. Diperlukan peningkatan pengelolaan dan pengembangan sarana prasarana objek wisata dalam menunjang kepuasan wisatawan Terkait dengan kebersihan dan keamanan pada objek wisata, perlu adanya penambahan petugas kebersihan dan keamanan, penambahan dan pemeliharaan tempat sampah dan toilet demi kenyamanan pengunjung,

2. Peningkatan promosi melalui media masa dan media elektronik secara berkala dalam menunjang peningkatan jumlah kunjungan wisatwan baik nasional maupun internasional.

3. Perlu adanya kerjasama dengan dinas terkait dalam menunjang kesiapan produk pendukung dan peningkatan kapasitas pengelolaan

\section{DAFTAR PUSTAKA}

Alwi, et al. 2013. Persepsi Pengunjung Terhadap Ketersediaan Sarana Penunjang Ruang Publik Kota Maea, Baubau, Sulawesi Tenggara Jurnal Wilayah Dan Kota Maritim Vol.1 No.1. Universitas Hasanudin [diakses tanggal 23 Februari 2019]

Baskara, Gusta Gerry. 2010. Analisis Kepuasan Pengunjung Kampoeng Wisata Cinangneng Dan Implikasinya Terhadap Bauran Pemasaran. Bogor [ID] :IPB [diakses pada 03 Maret 2018]

Botha, et al. 2015. Persepsi Pengunjung Terhadap Pengelolaan Kawasan Wisata Bukit Kasih Kanonang. Manado[ID] : Universitas Sam Ratulangi [diakses pada 08 November 2018]

De Fretes, Vety Vera 2015. Studi Potensi Daya Tarik Objek Wisata Alam Teluk Sawai Kabupaten Maluku Tengah. Ambon[ID] Skripsi Universitas Pattimura.

Dinas Pariwisata Kabupaten Seram Bagian Timur, 2017. Data Jumlah Kunjungan Wisatawan Mancanegara Dan Wisatawan Nusantara Tahun 2017.

Dwiputra, Roby. 2013. Preferensi Wisatawan Terhadap Sarana Wisata di Kawasan Wisata Alam Erupsi Merapi Jurnal Perencanaan Wilayah dan Kota, Vol. 24 No. 1. Jakarta[ID]. Badan Perencanaan dan Pembangunan Nasional [internet] [diakses tanggal 12 September 2018]

Ervinawati, et al. 2012. Penilaian Daya Tarik Objek Wisata Pantai Putri Serayi Kecamatan Jawai Selatan Kabupaten Samba. Pontianak[ID]. Universitas Tanjungpura [diakses tanggal 19 September 2018] 
Febrianti, et al. 2016 Persepsi Dan Preferensi Masyarakat Pesisir Terhadap Pembangunan Reklamasi Di Kawasan Pantai Salemo Kota Palopo, Sulawesi Selatan. Manado[ID]. UNSRAT [diakses tanggal 26 Februari 2018]

Ismayanti, 2010. Pengantar pariwisata. Jakarta[ID]. Grasindo.

Jainuri, et al. 2014. Penilaian Daya Tarik dan Pengembangan Objek Wisata Pantai Tanjung Belandang Di Kabupaten Ketapang. Pontianak[ID]. Universitas Tanjung Pontianak [diakses pada tanggal 28 Maret 2018]

Keliwar Said dan Nurcahyo Anton. 2015. Motivasi Dan PersepsiPengunjung Terhadap Obyek Wisata Desa Budaya Pampang Di Samarinda. Samarinda[ID] : Politeknik Negeri Samarinda [diakses pada tanggal 08 November 2018].

Koranti, et al. 2017 Analisis Preferensi Wisatawan Terhadap SaranaDi Wisata Taman Wisata Kopeng. Jakarta[ID]: Universitas Gunadarma. [diakses tanggal 28 Agustus 2018].

Kurniawan, Sandy. 2013 Analisis Persepsi Dan Preferensi Pengunjung Serta Tingkat Kesejahteraan Pedagang Di Lokasi Taman Margasatwa Ragunan Jakarta. Bogor[ID]: IPB. [internet] [diakses tanggal 23 Febriari 2018].

Lase, Monaria. 2014. Keanekaragaan Makroalga Di Sekitar Pantai Desa Fodo Kota Gunungsitoli. Medan [ID]. Universitas Sumatera Utara [diakses taggal 15 September 2018].

Latupapua, Y Th., 2011 Persepsi Masyarakat Terhadap Potensi Objek Daya Tarik Wisata Pantai Di Kecamatan Kei Kecil Kabupaten Mauluku Tenggara. Jurnal Agroforestri Vol. VI No.2 : Ambon [ID]. Universitas Pattimura [diakses tanggal 20 September 2018]
Pauwah, et al. 2013. Persepsi Dan Preferensi Pengunjung Terhadap Kawasan Wisata Pantai Malalayang. Sabua Vol. 5, No.1 : Manado[ID]. UNSRAT [diakses tanggal 19 Januari 2018].

Rare, et al. 2017. Identifikasi Potensi Obyek Wisata Pantai Tanjung Kayu Angin Di Desa Liku Kecamatan Samaturu Kabupaten Kolaka Jurnal Pendidikan Geografi Vol.1 No.1 [diakses tanggal 20 September 2018].

Republik Indonesia. 2009. Undang-Undang Republik IndonesiaNomor 10.Tahun 2009TentangKepariwisataan.Lembar an Negara RI tahun 2009, No. 11. Sekretariatan Negara. Jakarta [diakses tanggal 23 Februari 2018].

Samehe V. J. Dan Kindangen P. 2015. Persepsi Isatawan Mancanegara Dan Kunjungan Wisata Di Kota Manado Sebagai Destinasi Ekowisata. Manado[ID] : Universitas Sam Ratulangi [diakses pada 25 Februari 2018].

Saragih, et al. 2015. Karakteristik Dan Motivasi Wisatawan Ekowisata Di Bali (Studi Kasus Di Jaringan Ekowisata Desa). Bali[ID] : UNUD [diakses pada tanggal 24 Februari 2018].

Sastrayuda, Gumelar S. 2010. Strategi Pengembangan Dan Pengelolaan Resort And Leisur. [diakses tanggal 19 September 2018] 